\title{
5. Crops Agents, Phytopathology and Ethical Review
}

\author{
Simon Whitby
}

\section{Introduction}

This chapter explores the dual-use quality of scientific research and technological development in the field of phytopathology (plant science). It offers a brief survey of naturally occurring pathogens that have been developed for use in weapons and considers areas of convergence and overlap between the hostile use of disease organisms as a form of warfare and the peaceful deployment of bio-control and plant inoculants. The relevance of bio-control agent and plant inoculant production to the Biological Weapons Convention (BWC) is then considered. Included in this chapter also is a snapshot of some significant developments in civil plant science, alluding to the scale and speed of progress in plant science and technology.

I argue that since they can be used for both peaceful and hostile purposes, plant science and technology raise issues of dual-use biosecurity concern that are thus worthy of ethical consideration. In this connection, this chapter argues that ethical review processes could usefully be located alongside deliberative processes that facilitate consideration of the legal and social implications of plant-science research. Deliberation regarding its potential as dual-use research of concern may therefore be best located within the context of a comprehensive system for oversight of scientific research such as that recommended by the US National Science Advisory Board for Biosecurity (NSABB). ${ }^{1}$ Therefore, a brief survey of the contours of the latter is included in the concluding section of the chapter, which focuses specifically on the role of the principal investigator (PI)'the most critical element in the oversight of dual-use life-sciences research'2 and the requirement to seek to ensure through improved awareness and training that PIs are sufficiently aware of dual-use research issues and concerns.

\footnotetext{
1 National Science Advisory Board for Biosecurity (NSABB) 2007, Proposed Framework for the Oversight of Dual Use Life Sciences Research: Strategies for Minimizing the Potential Misuse of Research Information, National Science Advisory Board for Biosecurity, Bethesda, Md.

2 Ibid., p. 11.
} 


\section{Deliberate disease for hostile purposes: Biological warfare}

As part of its offensive biological warfare program that originated in the early 1940s, the United States developed an extensive anticrop program that resulted in the production, development, stockpiling and assimilation of anticrop chemical and biological weapons agents. As is well documented, ${ }^{3}$ chemical anticrop agents and defoliants were utilised extensively during the course of offensive operations in Vietnam in the 1960s and 1970s.

A range of biological warfare anticrop agents was the focus of extensive research and development during the course of the offensive US anticrop program between the mid 1940s and 1969, and research on production, scaleup, storage, dissemination and effectiveness saw the standardisation of agents for crop destruction with targets including both staple food crops and narcotics production. Since the United States provides an example of a systematic offensive program from research to assimilation, attention will turn briefly to list the agents standardised for the conduct of anticrop warfare.

Agents in the US stockpile as documented ${ }^{4}$ in 1970, including for the destruction of food crops, are listed in Table 5.1. An early attempt to identify agents for the destruction of narcotics crops is also included.

Table 5.1 US Stockpiles in 1970 for Food Crop Destruction

\begin{tabular}{|l|l|l|}
\hline Agents category & Type & Hosts \\
\hline $\begin{array}{l}\text { Category A } \\
\text { agents }\end{array}$ & Stem rust of wheat & Wheat, barberry and certain grasses \\
\hline \multirow{2}{*}{$\begin{array}{l}\text { Category B } \\
\text { agents }\end{array}$} & Rice blast & Rice, possibly some other grasses \\
\cline { 2 - 3 } $\begin{array}{l}\text { Category C } \\
\text { agents }\end{array}$ & Stripe rust of wheat & Wheat, barley, various grasses \\
\cline { 2 - 3 } & Boja blanca of rice & $\begin{array}{l}\text { Rice, wheat, corn, barley, rye, sorghum and } \\
\text { various other grasses }\end{array}$ \\
\cline { 2 - 3 } & Downy mildew of poppy & Species of Papaver and Argemone \\
\hline
\end{tabular}

Source: Stockholm International Peace Research Institute (SIPRI) 1973, The Problem of Chemical and Biological Wafare, vol II, Stockholm International Peace Research Institute, Stockholm.

3 Cecil, F. 1986, Herbicidal Warfare: The RANCH HAND Project in Vietnam, Praeger, New York. See also, Karnow, S. 1997, Vietnam: A History, 2nd edn, Penguin, New York.

4 Stockholm International Peace Research Institute (SIPRI) 1973, The Problem of Chemical and Biological Wafare, vol II, Stockholm International Peace Research Institute, Stockholm. 
Following President Richard Nixon's unilateral renouncement of offensive biological warfare in 1969 the stockpile scheduled for destruction ${ }^{5}$ in 1970 included $158684 \mathrm{lb}(71 \mathrm{t})$ of the causal agent of wheat rust, and $1865 \mathrm{lb}$ (846 $\mathrm{kg}$ ) of the causal agent of rice blast (as well as munitions for their deployment).

In a 1980s study based on publicly available secondary sources, Geissler noted that prior to 1969 - at a time of an emerging international consensus towards the agreement of a complete ban on biological warfare - the majority of military work on pathogens had involved bacteria and fungi. The last included those agents that were developed to attack some of the world's most economically and socially significant food and cash crops. In a program of research and development that appeared to parallel the US biological weapons (BW) program, Iraq's modest late-1980s attempts to conduct research and development into crop warfare also focused on investigations into the effectiveness of fungal plant pathogens. ${ }^{6}$ According to Geissler, though, by 1983, the majority of military work on pathogens had switched from bacteria and fungi to instead focus on investigations into the effectiveness of viruses.

The latter featured as agents of choice in what might be regarded as 'secondgeneration' programs, not least as they appear to have featured in work in the former Soviet Union. ${ }^{7}$ With the advent of genetic-engineering techniques, Geissler noted a renewed military interest in biological warfare post 1981, with Dr Kenneth Alibek ${ }^{8}$ (a former Soviet biological weapons scientist) subsequently alluding to activities in the former Soviet Union in the early 1980s that included investigations into the production of genetically engineered antibiotic strains of a number of zoonotic, and antipersonnel agents, including anthrax and glanders. According to Geissler, these events were characteristic of the emergence of a 'third generation' of scientific and technological applications in offensive biological warfare. Although there is no publicly available information relating to third-generation research and development in offensive anticrop military programs, it would be unwise to rule out the possibility of improvements in destructive effectiveness. Indeed, outside military programs, ample evidence suggests that routine genetic manipulation is being deployed for peaceful purposes in the burgeoning area of research, development and deployment of bio-control agents and plant inoculants in agriculture.

5 Ibid.

6 United Nations Special Commission (UNSCOM) 1995, Report to the Secretary-General, 11 October.

7 Tucker, J. 1999, 'Biological weapons in the former Soviet Union: an interview with Dr. Kenneth Alibek',

The Nonproliferation Review, (Spring-Summer), p. 2.

8 Ibid. 


\section{Peaceful bio-control that could serve biological warfare}

The focus of research in this area was in the development and deployment of naturally occurring pathogens and insects in the protection of crops from disease caused by pathogens and disease caused or transmitted by insect vectors. The deployment of bio-control agents and plant inoculants marks this area out as distinct since their use for peaceful purposes is not prohibited by the 1972 BWC. Nevertheless, during the course of talks to negotiate a legally binding protocol to strengthen the effectiveness and improve the implementation of the BWC in the 1990s and early 2000s, discussion focused on initiatives intended to ensure that scientific and technological developments in this area were in compliance with the objectives and scope of the convention.

In a statement ${ }^{9}$ by the South African delegation to the Fifth Review Conference, on 19 November 2001, Peter Goosen, Department of Foreign Affairs, reminded states parties that in all of their work related to the BWC the threat against plants was usually considered to be of a lower priority than the threat against humans. This had occurred, Goosen pointed out, in spite of the widespread appreciation amongst states parties that major elements of biological weapons programs since the 1920s had been directed against crops and that numerous plant pathogens had been researched, developed and produced together with weapons as part of offensive BW programs for the purpose of the widespread dissemination of anticrop agents. ${ }^{10}$

No clear distinctions, however, separate pathogens in this area from those deployed in offensive biological warfare programs. Bio-control agents are living organisms, such as bacteria, fungi, insects, mites or weeds, or microorganisms that are used in the control of microbes or other organisms. A large number of biocontrol agents are currently available - for example, in the United States, where they are marketed as bio-pesticides and include bacteria such as Agrobacterium, the widely used Bacillus thuringiensis that produces a protein toxic to species of insect pests belonging to the orders Lepidoptera (caterpillars), Diptera (flies) and Coleoptera (beetles and weevils), Pseudomonas and Streptomyces. Further bio-pesticides include fungi such as Ampelomyces, Candida, Coniothyrium

\footnotetext{
9 Goosen, P. 2001, Statement by Chief Director: Peace and Security, Department of Foreign Affairs, Pretoria, South African Delegation to the Fifth Review Conference of the Convention on the Prohibition of the Development, Production, and Stockpiling of Bacteriological (Biological) and Toxin Weapons and on their Destruction, Geneva, 19 November, <http://www.opbw.org/rev_cons/5rc/docs/statements/5RC-OSSAFRICA.pdf $>$.

10 For a systematic study of such state offensive anticrop biological warfare programs, see: Whitby, S. 2001, Biological Warfare against Crops, Palgrave, London.
} 
and Trichoderma. ${ }^{11}$ Plant inoculants are formulations containing living microorganisms, used in the treatment and propagation of seeds and plant propagation matériel for enhancing growth and disease resistance in plants. They are also used for the restoration of the microflora of soil. Indeed the technologies associated with the dissemination of such agents appear to equate with those used in the dissemination of biological warfare agents.

Prior to the First Review Conference of the BWC, the Preparatory Committee requested that depositary governments prepare a background paper ${ }^{12}$ on new scientific and technological developments relevant to the convention and invited states parties to submit their views on new scientific and technological developments relevant to the convention. Prepared by experts of the depositary governments, the review ${ }^{13}$ focused on new scientific and technological developments relevant to the convention and looked inter alia at the microbial control of pests. ${ }^{14}$ Since significant environmental and human health implications arose from the deployment of synthetic chemical pesticides that had seen extensive use in Vietnam, this section of the report noted environmental and human health concerns and questioned the efficacy of the use of agents against plants that might develop resistance to their use. The review noted, however, that there had been a remarkable increase in interest in this area. This was summarised as follows:

Microbiological methods involve the large-scale production of certain live micro-organisms or their extractable toxins, the formulation of a liquid or powder product and dissemination of the product by vehicle or aircraft-borne sprays (or in rodent control, the use of ground bait) over crops or forests. With live microbial agents death of insect or rodent occurs through infection; with microbial toxins death is produced by toxic effects. In some basic respects the whole sequence resembles biological warfare. [Emphasis added]

Table 5.2 illustrates the methods of production and dissemination of viral, bacterial and fungal bio-control agents of relevance to the BWC.

\footnotetext{
11 McSpadden Gardener, B. B. and Fravel, D. R. 2002, 'Biological control of plant pathogens: research, commercialisation, and application in the USA', Plant Health Progress, [Online], < doi:10.1094/PHP-20020510-01-RV>.

12 Report of the Preparatory Committee for the Review Conference of the Parties to the Convention on the Prohibition of the Development, Production, and Stockpiling of Bacteriological (Biological) and Toxin Weapons and on their Destruction, BWC/CONF.I/5, 6 February 1980, <http://www.opbw.org >.

13 Not all states parties submitted information to the Secretary-General of the United Nations that referred either directly or indirectly to potential problems posed by the use of microbial agents against crops. For the purpose of this discussion, it has been necessary to refer selectively to the official documentation.

14 Report of the Preparatory Committee, op. cit., Appendix E.
} 
The United Kingdom's contribution ${ }^{15}$ to a subsequent BWC Review Conference focused also on the microbial control of pests. It included an assessment of increased interest in biological control and noted apparent changes to the methods of production: ${ }^{16}$

Increases in use since 1980 have not been spectacular except possibly in the nations of Eastern Europe, where Lepidoptera pests are a greater agricultural problem than elsewhere. In such nations about 30 different microbial preparations or formulations have been developed and some are produced on often multi-tonne scales. GE [genetic engineering] is being applied in many nations to the development of improved and novel agents for pest control. Obviously large-scale industrial microbiology is a key aspect of production ... Insect viruses for pest control continue to be relatively expensive to produce but the possibility that viruses could be more cheaply and effectively produced through GE, rather than by bulk production in insects, is likely to result in widely-adopted production methods in nations where susceptible pests are a problem.

\section{Table 5.2 Methods of Production and Dissemination of Viral, Bacterial and Fungal Bio-control Agents}

\begin{tabular}{|l|l|}
\hline Viruses & $\begin{array}{l}\text { Nuclear polyhedrosis and granulosis viruses: produced on a large scale by } \\
\text { a few nations, using mass rearing of insect hosts. The viruses extracted at } \\
\text { a concentration of } 12 \times 10^{6} \text { infective units/ml are sprayed by aircraft. Viral } \\
\text { insecticides are more expensive to produce than bacterial insecticides but they } \\
\text { have the possible advantage of high target specificity. }\end{array}$ \\
\hline Bacteria & $\begin{array}{l}\text { Bacillus thuringiensis: produced by several nations on a multi-tonne basis } \\
\text { in deep-aerated vessels. The final product contains about } 3 \times 10^{10} \text { bacterial } \\
\text { spores/g, and is stable for two to three years. Disseminated by aircraft spray as } \\
\text { liquid or powder aerosol, the bacterium is highly valued for controlling a wide } \\
\text { variety of insect pests. }\end{array}$ \\
\cline { 2 - 3 } & $\begin{array}{l}\text { Bacillus popilliae: another agent produced and used in much the same way as } \\
\text { Bacillus thuringiensis for controlling Japanese beetle larvae. }\end{array}$ \\
\cline { 2 - 3 } & $\begin{array}{l}\text { Pseudomanas seruginosa (and Pl. fluorescens) and Chromobacterium } \\
\text { prodigiosum: produced and used in a few countries for dissemination by aircraft } \\
\text { spray on reservoirs (at } 10 \times 10^{6} \text { organisms/sq cm water surface) in mosquito } \\
\text { larvae control. These agents are, however, facultative* pathogens for humans. }\end{array}$ \\
\hline Fungi & $\begin{array}{l}\text { Various species such as Trichoderma, Sporotrichum, Beauveria and } \\
\text { Cuelomemvces are produced on a multi-tonne basis by several nations. They are } \\
\text { disseminated by aircraft spray to infect insect pests and sometimes to attack } \\
\text { other fungal diseases of crops. Additionally, a number of other microbial agents } \\
\text { are currently being studied or evaluated in field trails. }\end{array}$ \\
\hline
\end{tabular}

* Facultative pathogens include those with mechanisms for infecting human body tissue.

Source: Report of the Preparatory Committee for the Review Conference of the Parties to the Convention on the Prohibition of the Development, Production, and Stockpiling of Bacteriological (Biological) and Toxin Weapons and on their Destruction, BWC/CONF.I/5, 6 February 1980, <http://www.opbw.org >.

15 Background Document on New Scientific and Technological Developments Relevant to the Convention on the Prohibition of the Development, Production and Stockpiling of Bacteriological (Biological) and Toxin Weapons and on their Destruction, BWC/CONF.11/4, '6. Microbial Control of Pests', p. 8, <http://www.opbw.org >. 
Regarding methods of dissemination for microbial methods of pest control, the UK contribution ${ }^{17}$ noted the following:

Methods of dissemination of microbial pest control agents continue to be the subject of increasing R\&D and trials. Mobile jet-engined devices are capable of disseminating agent aerosols, notably insect viruses, over vast tracts of land. There has been continuing R\&D on ultra-low volume spraying systems, methods of studying spray deposition, formulations, the problems of disseminating dusts and powders, micro-encapsulation and other relevant topics.

A section on developments of relevance to the BWC in regard to the microbial control of pests was also included in the UK contribution, which noted the following (Table 5.3).

Table 5.3 Microbial Control of Pests

\begin{tabular}{|l|l|}
\hline a. & GE-derived bacteria with high toxin yields. \\
\hline b. & $\begin{array}{l}\text { The production through GE of toxins in species beyond those bacteria that produce } \\
\text { them in nature. }\end{array}$ \\
\hline c. & $\begin{array}{l}\text { Development of formulations aimed at enhanced retention of microbial viability during } \\
\text { storage and in aerosol. }\end{array}$ \\
\hline d. & $\begin{array}{l}\text { Protection of aerosolised micro-organisms by the incorporation of protective UV-light } \\
\text { screening dyes. }\end{array}$ \\
\hline e. & Improvements in the spray-drying and milling of micro-organisms and toxins. \\
\hline f. & $\begin{array}{l}\text { The formulation of synergistic combinations of live micro-organisms and toxic } \\
\text { anticoagulants, together with drug-delivery systems. }\end{array}$ \\
\hline g. & $\begin{array}{l}\text { Development of automated production lines for insects, used in the production of } \\
\text { some viruses. }\end{array}$ \\
\hline h. & $\begin{array}{l}\text { Vastly increased knowledge of aerobiological aspects of dissemination and the } \\
\text { elucidation of the factors that control viability and stability in dissemination, aerosol } \\
\text { and in respect of persistence. }\end{array}$ \\
\hline i. & Computer-controlled continuous culture systems and improved purification systems. \\
\hline
\end{tabular}

Source: Report of the Preparatory Committee for the Review Conference of the Parties to the Convention on the Prohibition of the Development, Production, and Stockpiling of Bacteriological (Biological) and Toxin Weapons and on their Destruction, BWC/CONF.I/5, 6 February 1980, <http://www.opbw.org >.

In its concluding remarks, the UK contribution noted a greater potential for abuse across a range of civil capabilities than was present at the time of the First BWC Review Conference in 1980. In particular, with regard to microbial methods of pest control, it noted

the 'biotechnology explosion' in the civil sectors of many nations and the realization of the potentials of GE and industrial microbiology. We have drawn attention again to developments in microbial methods of pest control and to the increasing knowledge of nations in the 
large-scale production and dissemination of micro-organisms and microbial products. Such developments in the civil sector are relevant to the BWC and could be abused to support offensive programmes.

The South African submission ${ }^{18}$ commented extensively and in considerable detail in regard to developments relating to plant inoculants and biological control relevant to the convention. In regard to plant inoculants, separate detailed subsections of the South African submission gave an overview of: the history of their use and development; their purpose; their mode of action; types of inoculants; methods of inoculation; production methods; and the relevance of plant inoculants for the BWC. And in regard to bio-control agents, separate detailed subsections of the South African submission gave an overview of: differing approaches to biological control; the complexity of factors affecting their application; and biological agents against plants - the last including the controversial area of attacking drug crops.

According to the South African submission, ${ }^{19}$ plant inoculants are relevant to the convention in terms of:

a. A growing industry and more sophisticated production facilities that have the potential to be diverted to BW producing facilities, as in the case of vaccine production facilities.

b. The genetic research and development that is conducted to improve the micro-organisms that form the active ingredients of inoculants.

c. The development of liquid inoculants that will make their application by spraying and aerosolisation a possibility.

In comparison, the control of plant pests, weeds and plants with biological control agents is relevant to the BWC in terms of:

a. The less clear distinction between the peaceful use of biocontrol agents and their use as BW due to the dual-use nature of these agents.

b. Undesired plants, exotic plants or even noxious plants in one country may be natural, essential and in many cases utilised for commercial purposes (crops) in other countries.

The failure of states parties at the Fifth Review Conference to produce a final declaration ${ }^{20}$ meant that the usual 'extended understandings' were not produced during the BWC in 2001-02; South Africa urged co-depositaries and

18 Ibid., para. 6.2, p. 5.

19 Ibid., para. 6.2 , p. 7

20 Pearson, G. S. and Sims, N. A. 2005, Preparing for the BTWC Sixth Review Conference in 2006, Bradford Review Conference Paper No. 10 (February), <http://www.brad.ac.uk/acad/sbtwc/briefing/RCP_10.pdf $>$. 
states parties to give careful consideration to the issues of biological control at the Sixth Review Conference of the Convention in 2006 and recommended that CBM declarations be extended to include animal and plant pathogen research and production facilities.

As noted by Kelle and colleagues ${ }^{21}$-and echoing some of the sentiments expressed by Geissler above-biological warfare capabilities have been determined by developments in the life sciences, but the genomics ${ }^{22}$ revolution has changed dramatically the nature and scope of biological warfare.

Recognition of the challenge posed by rapid advances in science and technology was, for example, included in the Final Declaration ${ }^{23}$ of the Second Review Conference of the Biological and Toxin Weapons Convention in 1986. Thus, such concern was embodied in additional understandings agreed on by states parties that:

The Conference, conscious of apprehensions arising from relevant scientific and technological developments, inter alia, in the fields of microbiology, genetic engineering and biotechnology, and the possibilities of their use for purposes inconsistent with the objectives of the Convention, reaffirms that the undertaking given by States Parties in Article 1 applies to all such developments.

Subsequent reviews by states parties of scientific and technological developments of relevance to the BWC have been conducted (on a voluntary basis) by states parties, and since 1980 submissions to the five-year reviews of the convention have noted that significant advances of relevance to the convention have taken place in the fields of biotechnology, genetic modification and genomics.

\footnotetext{
21 Kelle, A., Nixdorff, K. and Dando, M. 2006, Controlling Biochemical Weapons: Adapting Multilateral Arms Control for the 21st Century, Palgrave, Basingstoke, UK, p. 35.

22 The sum total of genetic information of an individual, which is encoded in the structure of deoxyribonucleic acid (DNA), is called a genome. The study of the genome is termed 'genomics'. Recently, the order of most of the chemical building blocks, or bases, which constitute the DNA of the genomes of human beings (estimated to amount to three billion), several other animal species and a variety of human pathogens and plants has been determined. Over the next few years this remarkable achievement will be completed and augmented by research into functional genomics, which aims to characterise the many different genes that constitute these genomes and their variability of action. Such research will also determine how these genes are regulated and interact with each other and with the environment to control the complex biochemical functions of living organisms, both in health and in disease.

23 Second Review Conference of the Parties to the Convention on the Prohibition of the Development, Production and Stockpiling of Bacteriological (Biological) and Toxin Weapons and on their Destruction, Final Document PART II Final Declaration, BWC/CONF.II/13/II, <www.opbw.org >.
} 


\section{Science and technology: Phytopathology}

In the field of phytopathology, it became apparent by 1996 that genomics would play an increasingly important role in plant biotechnology, and 2006 marked a decade of important scientific and technological developments. During the course of this period plant science provided a glimpse into the huge agronomic and social potential of plants.

In recognition of the fulfilment of objectives set by the Arabidopsis genome initiative in 1996, a news article in a December 2000 edition of Nature, ${ }^{24}$ titled 'A green chapter in the book of life: the sequencing of an entire plant genome is now complete ...', and the genome analysis in the same edition, signalled a landmark in plant science. The sequencing of the remaining three of five chromosomes, and therefore of the complete gene of Arabidopsis thaliana, a small flowering plant that is a member of the mustard family commonly known as thale cress, represented a major scientific and technological breakthrough, with Arabidopsis representing a model organism in plant biology. This development opened up the possibility of investigating the genetic complexity of more economically and socially significant plant life. Citing Bonny, the World Health Organisation (WHO) ${ }^{25}$ highlights the further potential benefits of the new science and technology thus: 'The potential uses of modern biotechnology in agriculture include: increasing yields while reducing inputs of fertilizers, herbicides and insecticides; conferring drought or salt tolerance on crop plants; increasing shelf-life; reducing postharvest losses; increasing the nutrient content of produce; and delivering vaccines.'

The cheap availability, short life cycle, small physical size and the small size of the Arabidopsis genome-118.7 million base pairs - relative to other more complex plants, meant that plant science was now able to undertake, under controlled conditions, the identification of the genes responsible for a wide range of physiological processes. In fundamental terms, finding the genes responsible for a plant's physiological response to, inter alia, light, soil and soil nutrients, bacterial, fungal and viral plant pathogens and insect pests, now promised to be much simpler.

Rapid progress in plant science was soon also made regarding the rice genome. The 10-nation International Rice Genome Sequencing Project announced the

\footnotetext{
24 Walbot, V. 2000, 'A green chapter in the book of life', Nature, vol. 408, p. 794. See also The Arabidopsis Genome Initiative 2000, 'Analysis of the genome sequence of the flowering plant Arabidopsis thaliana', Nature, vol. 408 (December), pp. 796-815.

25 World Health Organisation (WHO) 2005, Modern Food Biotechnology, Human Health and Development: An Evidence-Based Study, World Health Organisation, Geneva, p. 37, <http://www.who.int/foodsafety/ publications/biotech/biotech_en.pdf $>$.
} 
sequencing of the second complete genome, ${ }^{26}$ that of rice, Oryza sativa, in 2005. The economic and social importance of rice is significant. Rice is the world's most important food crop, consumed by more than half of the world's population, and to meet projected demand over the next 20 years production will have to rise by an estimated 30 per cent.

In connection with progress in plant science outlined above, a first generation of genetically modified crop products that have emerged in the marketplace over the past decade has expressed a limited number of characteristics. In particular, since 1996, millions of acres have been used for the production of genetically modified crops with, in the case of the United States, large-scale production of modified varieties of corn, cotton and soya (soya beans) enhanced by gene-transfer techniques that confer herbicide tolerance and insect resistant in crops. According to the International Service for the Acquisition of AgriBiotech Applications report Global Status of Biotech Crops, ${ }^{27}$ as early as 2005 the United States had approximately 49.8 million ha planted with crops that were the product of genetic modification. The extent to which some of these crops have been adopted in US agriculture and the short time span over which this has taken place are perhaps indicative of the willingness with which agricultural enterprises in the United States have embraced such technologies in spite of concerns raised regarding human health and the environment. According to the US Department of Agriculture (USDA), ${ }^{28}$ planting of herbicide-tolerant soya beans expanded from 17 per cent of US soya bean acreage in 1997 to more than 85 per cent in 2005. Planting with herbicide-tolerant cotton expanded from 10 per cent of US acreage in 1997 to more than 60 per cent in 2005. Planting with insect-resistant transgenic corn and cotton containing the Bacillus thuringiensis $(B t)$ toxin gene also increased significantly over this period in the United States. USDA figures ${ }^{29}$ for 1995 reveal the '[a]doption of all GE cotton, taking into account the acreage with either or both HT and Bt traits, reached 79 percent in 2005, versus 87 percent for soybeans. In contrast, adoption of all biotech corn was 52 percent'.

According to the International Service for the Acquisition of Agri-biotech Applications (ISAAA), ${ }^{30}$ global biotech planting had exceeded 1 billion ha by 2010.

\footnotetext{
26 For an analysis of some of the salient features of the rice genome, see: International Rice Genome Sequencing Project 2005, 'The map-based sequence of the rice genome', Nature, vol. 436 (August), p. 793.

27 Available at: <http://www.isaaa.org/>.

28 United States Department of Agriculture (USDA) n.d., Adoption of Genetically Engineered Crops in the U.S.: Extent of Adoption, Economic Research Service, United States Department of Agriculture, Washington, DC, <http://www.ers.usda.gov/Data/biotechcrops/adoption.htm $>$.

29 Ibid.

30 International Service for the Acquisition of Agri-biotech Applications (ISAAA) 2010, Global Status of Commercialized Biotech/GM Crops: 2010, ISAAA Brief, <http://www. ISAAA.org >.
} 
In the past two decades, genome studies have facilitated manipulation of the genetic characteristics of food crops. Crops can now be produced with built-in defences against insect pathogens such as Bacillus thuringiensis. They can also be manipulated to delay ripening, as in the case of the slow-ripening Flavr Savr tomato, which was approved for sale in the United States in 1994. Infertility can be conferred on plant seeds, as in the case of the controversial Terminator gene.

Plant science is, however, now beginning to focus on a second generation of crops that have been genetically modified to express a broader and more complex range of plant traits. The challenge now also extends to assigning functions to genes, and in the case of Arabidopsis much work ${ }^{31}$ had been done by 2007. According to a recent edition of Current Opinion in Plant Biology, ${ }^{32}$ advances in understanding at the level of functional genomics will result, in the case of Arabidopsis, in:

An understanding of the networks through which these genes interact to control plant development, metabolism, reproduction and other fundamental processes will accelerate the advent of a new generation of improved crop products to benefit growers, processors and consumers.

Bringing together knowledge of the function of genes and gene networks, and of their regulation within the contexts of cell, organ, organism, and environment will be crucial for achieving the level of precision in crop engineering that will be required to fuel the development of the nextgeneration products.

Considerable progress has been made in regard to the re-annotation ${ }^{33}$ including both the structure and the functions of genes - of the gene sequences of Arabidopsis, and a similar re-annotation of rice is also under way.

The revolution in genomics signals a transition in plant biology from a descriptive to a predictive science. As Dixon ${ }^{34}$ points out: 'Genomics (originally DNA and transcript based, but recently extended to integrate the proteome and metabolome) has revolutionized the speed of gene discovery for important plant traits.'

31 Lan, H., Carson, R., Provart, N. J. and Bonner, A. J. 2007, 'Combining classifiers to predict gene function in Arabidopsis thaliana using large-scale gene expression measurements', BioMedCentral, <http://www. biomedcentral.com/1471-2105/8/358>.

32 Salmeron, J. and Herrera-Estrella, L. 2006, 'Plant biotechnology: fast-forward genomics for improved crop production', Current Opinion in Plant Biology, vol. 9, pp. 177-9.

33 Rensink, W. A. and Buell, R. C. 2005, 'Microarray expression profiling resources for plant genomics', Trends in Plant Science, vol. 10, no. 12 (December).

34 Ibid. 
Indeed a brief review of scientific and technological developments emerging since the turn of the twenty-first century offers a glimpse into the broad range of activities relating to a more sophisticated understanding of the function of plant genomes.

A feature article ${ }^{35}$ published by the American Phytopathological Society (APS) in 2000 described four significant areas of research and possible future approaches involving genetic-engineering techniques that could confer plant resistance to pathogen invasion. Research focused on enhancing resistance with plant genes sought to identify the genes involved in defences against, and resistance to, plant pathogens (resistance is against pathogens, rather than diseases) to facilitate the conferring of disease resistance. Use of this approach increased the plant's ability to defend itself against pathogen invasion, and plant biologists using recombinant DNA biotechnology could now adopt a number of new strategies. As Fermin-Munoz ${ }^{36}$ demonstrated, the insertion of a specific transgene conferred resistance not normally present in a host plant. The insertion of transgenes also could trigger a plant's intrinsic defence mechanism against both pathogen invasion and abiotic stress. Also described were similar techniques for the insertion of proteinaceous and non-proteinaceous compounds having antibacterial and antifungal properties. One such example has led to the discovery of a protein called harpin (produced by members of the plant pathogenic bacterial genus Erwinia, which is sometimes thought of as a toxin and sometimes as a defence chemical) that could be used prior to pathogen invasion to activate crop defences.

Another approach ${ }^{37}$ was developed to protect plants from pathogen invasion through 'pathogen-derived resistance'. This strategy involved engineering genes into plants, and important recent work has included the insertion of viral transgenes as an alternative to the use of harmful pesticides against insect vectors. Pioneering research has shown that both protein-mediated and RNAmediated pathogen-derived resistance can be conferred using viral transgenes, with some success being achieved using a number of plant viruses ${ }^{38}$ affecting alfalfa, cucumber, tobacco, tomato and potato.

\footnotetext{
35 Fermin-Muñoz, G. A., Meng, B., Ko, K., Mazumdar-Leighton, S., Gubba, A. and Carroll, J. E. 2000, 'Biotechnology: a new era for plant pathology and plant protection', APSnet Feature, May, <http://www. apsnet.org/publications/apsnetfeatures/Pages/Biotechnology.aspx $>$.

36 Fermin-Munoz, G. A. 2000, 'Enhancing a plant's resistance with genes from the plant kingdom', APSnet Feature, May, <http://www.apsnet.org/publications/apsnetfeatures/Pages/EnhancingPlantResistance.aspx $>$. 37 Meng, B. and Gubba, A. 2000, 'Genetic engineering: a novel and powerful tool to combat plant virus diseases', APSnet Feature, May, <http://www.apsnet.org/publications/apsnetfeatures/Pages/ GeneticEngineering.asp $\mathrm{x}>$.
}

38 Ibid. 
Another approach ${ }^{39}$ for conferring plant disease resistance involves antimicrobial peptides and proteins that confer antimicrobial properties, thus strengthening immunity and resistance to fungal and bacterial plant pathogens. This review noted that proteins potentially useful in improving plant disease resistance could be found outside the plant kingdom in insects, animals, humans and fungi. Antibacterial peptides/proteins and enzymes have been shown to inhibit pathogen invasion in a variety of plants including some of considerable socioeconomic significance. Furthermore, immunity or resistance to pathogen invasion has been attempted at the molecular level by in planta expression of an antibody against a protein necessary for pathogenesis.

The past decade has seen continued progress in the development of plant disease-resistance mechanisms, and a wide array of new tools is being developed to produce plants expressing a broader range of such traits. Interesting areas of development were described in 2005 in Trends in Plant Science. ${ }^{40}$

In China, Wang et al. ${ }^{41}$ focused on improving rice, applying molecular markerassisted breeding, functional genomics and genetic modification techniques to the identification of gene function in elite rice cultivars having important socioagronomic traits such as enhanced pest and stress resistance, good grain quality, and high and stable yield potential.

In the area of molecular marker-assisted breeding, which is the application of molecular biotechnologies to breeding, tools include marker-assisted selection (MAS), quantitative trait locus (QTL) analysis, and genetic transformation techniques. While plant scientists have enjoyed success in improving cultivars with important traits using genes with known desirable traits, the adoption of molecular marker-assisted breeding techniques may facilitate the identification of desirable plant traits that result from the expression of multiple genes.

Wang et al. also delved into functional genomics, ${ }^{42}$ demonstrating how microarrays, reverse genetics and map-based cloning are being used for identifying important characteristics in rice genes, including '[e]xpression pattern, chromosomal position, perceived biological function, and behaviour of alleles under phenotypic selection'.

39 Ko, K. 2000, ‘Using antimicrobial proteins to enhance plant resistance in biotechnology: a new era for plant pathology and plant protection', APSnet Feature, May, <http://www.apsnet.org/publications/ apsnetfeatures/Pages/AntimicrobialProteins.aspx>.

40 Dixon, R. A. 2005, 'Plant biotechnology kicks off into the 21st century', Trends in Plant Science, vol. 10, no. 12; Neal-Stewart, C., jr, 2005, 'Plant functional genomics: beyond the parts list', Trends in Plant Science, vol. 10, no. 12 (December).

41 Wang, Y., Xue, Y. and Li, J. 2005, 'Towards molecular breeding and improvement of rice in China', Trends in Plant Science, vol. 10, no. 12 (December), pp. 610-14.

42 Ibid. 
Although scientists have had some success in the development of transgenic crops with resistance to plant disease and plant pests, a number of hurdles, not least those relating to public health and the environment, have (in China) thus far prevented the widespread commercialisation and human consumption of rice varieties with improved traits.

In their article 'Microarray expression in profiling resources for plant genomics' ${ }^{43}$ Rensink and Buell discuss various approaches to facilitate the identification of gene function and understanding of, inter alia, basic physiology, developmental processes and environmental stress responses, using information derived from micro-array platforms. They note, in particular, the significance for plant researchers of micro-array-derived bio-information and the importance of the worldwide availability, via the Internet, of bioinformatics data sets.

Likewise, in the article 'Genomics-assisted breeding for crop improvements', ${ }^{44}$ Varshney et al. note the importance of information on molecular markers (functional markers), and the relevance of the rapidly advancing area of bioinformatics, which is providing a means for the integration and structured interrogation of data sets that will facilitate cross-fertilisation of disciplines in the evolution of future genomics-assisted breeding.

A 2006 review in Current Opinion in Plant Biology $y^{45}$ provided a further glimpse into research in functional genomics. For example, Bohnert et al. describe a 'palette of tools' that facilitates a more detailed understanding of the spectrum of plant responses to developmental and environmental stimuli, including tolerance to drought, soil salinity and cold stresses. According to Salmeron and Herrera-Estrella, ${ }^{46}$ tools such as metabolite and protein profiling, subcellular imaging, transcript clustering, comparative biology and reverse genetics reveal a range of valuable genes, alleles and promoters. Research by Valliyodan and Nguyen in the same edition shows understanding of abiotic stress tolerance, 'specific gene components' and transcriptional and cis-acting regulatory elements important in possible future engineering of specific plant traits has progressed significantly.

A review of work by Fernie et al. ${ }^{47}$ describes progress in the development of genomics-based techniques that use molecular markers in the identification of desirable plant trait alleles. According to Salmeron and Herrera-Estrella: ${ }^{48}$

43 Rensink and Buell, op. cit.

44 Varshney, R. K., Grner, A. and Sorrells, M. E. 2005, 'Genomics-assisted breeding for crop improvement',

Trends in Plant Science, vol. 10, no. 12 (December), pp. 621-30.

45 Salmeron and Herrer-Estrella, op. cit., pp. 177-9.

46 Ibid.

47 Ibid.

48 Ibid. 
'Genomics will make possible a level of surgical precision in breeding that allows such traits to be efficiently extracted by using molecular markers to tag specific desirable alleles.'

Alleles of importance for plant traits such as those related to nutrition and yield have already been identified in some solanaceous and other important crops. Also reviewed by van Schie et al. in the same edition is research on plant fragrance mechanisms, and the possibility that it could be manipulated at the genome level.

A further article on functional genomics centres on emerging techniques for gene silencing using geminiviral vectors. Salmeron and Herrera-Estrella ${ }^{49}$ outline some possible applications as follows:

1) $[\mathrm{T}]$ hey can be used for functional genomics in plants species for which the production of transgenic lines is difficult or time-consuming; 2) they provide the ability to work with genes whose knockout mutants are lethal; 3) inoculation with Gemini viral vectors is rather simple and phenotypes can be analysed a few days after the host has been infected; and 4) they can be adapted easily for high-throughput genomic studies.

\section{Malign applications}

The above developments offer a glimpse of the rapid progress in plant biology over the past 10 years. The genomics revolution opens up a range of new possibilities for improvements in the quality and quantity of crop yields and an increasing number of techniques and applications will become available for combating disease that is caused naturally and accidentally; however, the same developments also open up a range of possibilities for malign applications.

Analysts have for many years expressed concern regarding the ways in which naturally occurring plant pathogens might be deployed for malign purposes. This might involve the simple introduction into a crop species, for example, of a pathogen to which no natural immunity exists. Van der Plank's well-known observations of the seemingly explosive spread of some plant pathogens in the absence of immunity remain particularly salient in spite of great progress that has been made in phytopathology over the past 40 years.

Scenarios may also include the introduction into crops of pathogens that have mutated naturally in the environment - witness, in this connection, the nearfuture possibility of the re-emergence in regions such as the Middle East and in countries such as India of a new and virulent strain of wheat rust, Ug99 
(Ug99 has been found in Egypt at least and perhaps other countries in the Middle East), and its predicted associated 'immense potential for social and human destruction' as it has been described by Borlaug ${ }^{50}$ in the New Scientist. According to Mackenzie, ${ }^{51}$ to combat this mutation effectively, the production of enough Ug99-resistant seed to plant our wheat fields might take up to eight years.

As in the case of bio-control agent production discussed above, there is also a possibility that crop pathogens could be genetically modified deliberately. The result could include increased toxicity or pathogenicity. Or, as suggested by Kelle et al., ${ }^{52}$ plants' innate immune systems are vulnerable to manipulation, possibly affecting the response to pathogen invasion. For example, a plant's response could be manipulated so as to trigger 'systemic', rather than localised, hypersensitive reactions to pathogen invasion. Nixdorff explains the mechanisms involved in systemic plant resistance mechanisms thus: 'The main systemic signals include salicylic acid, jasmonate and ethylene, which are produced in response to wounding and insect attack. $\mathrm{H} 2 \mathrm{O} 2$ is ... the most important' response mechanism to pathogen invasion

involved in downstream signalling, leading to the activation of signalling cascades in Arabidopsis as well as activation of genes controlling the production of proteins involved in HR [hypersensitive reaction]. [Therefore] ... plants may be attacked through their innate immune systems, for example, by targeting either the receptors of signalling cascades, or by inhibiting or producing an over-reaction in a signalling cascade with the use of inhibitors of key components in that cascade.

Kagan et al. ${ }^{53}$ present concerns about the introduction of noxious DNA material in the form of, for example, a bio-regulator into a bio-control agent such as Bacillus thuringiensis in quantities sufficiently large to contaminate a food product. Indeed, further to this, Chofness et al. ${ }^{54}$ also note in relation to transgenic plants that such plants

could be malevolently engineered to produce large quantities of bioregulators or toxic proteins, which could either be purified from plant cells or used directly as biological agents. As with legitimate production, using transgenic plants as bioreactors would eliminate the

50 Mackenzie, D. 2007, 'Rusting defences in the battle for wheat', New Scientist, 3 April.

51 Mackenzie, D. 2007, 'Billions at risk from wheat super-blight', New Scientist, 3 April, pp. 6-7.

52 Kelle et al., op. cit., p. 76.

53 Kagan, E. 2006, 'Bioregulators as prototypic nontraditional threat agents', Clinics in Laboratory Medicine, vol. 26, no. 2 (June), pp. 421-43.

54 Choffnes, E. R., Lemon, S. M. and Relman, D. A. 2006, 'A brave new world in the life sciences, the breadth of biological threats is much broader than commonly thought and will continue to expand', Bulletin of Atomic Scientists, vol. 62, no. 5 (September-October), pp. 26-33. 
need for mechanical equipment normally associated with the process. The technology would be limited to producing protein-based agents. But because transgenic plants would be largely indistinguishable from non-transgenic crops, biopharming could potentially provide a covert means for producing large amounts of product.

\section{Conclusion}

This survey of offensive biological warfare agents, bio-control agents and plant inoculants of relevance to the BWC, and recent trends in phytopathology and plant technology, has alluded to a broad range of scientific discovery and technological innovation. This highlights a number of areas where consideration - including ethical deliberation - regarding the dual-use nature of scientific discovery and technological application might usefully be applied. Indeed, where deliberation might take place, who might be involved, and what mechanisms and systems might be put in place to facilitate deliberative processes have been the subjects of considerable attention in the United States.

Since 2006, the NSABB has been tasked, ${ }^{55}$ inter alia, with advancing thinking around proposals for the development of recommendations for scientific oversight measures and for recommending how such measures might be developed so as to minimise the risk of misuse of scientific information. One of the challenges inherent in pursuing this mandate is how oversight mechanisms might be created that are both efficient and effective but constructed and implemented in such a way as to mitigate the stifling of life-science innovation. This initiative was viewed as a preliminary step towards establishing a mechanism of oversight through the development and implementation of a comprehensive system for the responsible identification, review, conduct, and communication of dual use research' ${ }^{56}$ The NSABB proposed that a system of oversight might include the following seven 'key features':

- The development of Federal Guidelines for oversight of dual use life science research

- Enhanced levels of awareness of dual use research of concern amongst practicing life scientists

- Enhanced, ongoing, mandatory education that raises awareness of dual use research of concern and addresses the roles and responsibilities of life scientists

55 See NSABB, op. cit., Appendix A, p. 9.

56 Ibid., p. 7. 
- With appropriately trained Principal Investigators, a system of local evaluation and review of research of dual use potential.

- Risk Assessment and Risk Management

- Mechanisms for Periodic Local and Federal Evaluation

- Local and Federal Mechanisms for ensuring Compliance. ${ }^{57}$

In regard to a system of 'local evaluation and review of research of dual use potential', the NSABB recommended that the initial evaluation of 'research for its potential as dual use research of concern' should fall to the principal investigator (PI). Indeed, as further noted by NSABB, appropriate expertise could thus be brought to bear in assessing the dual-use potential of scientific research, but significantly NSABB also noted a requirement in this area for 'appropriate training' ${ }^{58}$

As part of its recommendations, NSABB identified a series of oversight roles and responsibilities and elaborated upon how both would relate to researchers, research institutions, institutional review entities, ongoing independent review and the Federal Government. In regard to the roles and responsibilities of researchers, NSABB noted a further potential deficit in the area of awareness and training. As it argued, PIs are the ones who will be best placed to discharge their responsibility to be able to assess the kinds of knowledge generated, its potential for misuse and how such threats might be mitigated. According to NSABB ${ }^{59}$ however, PIs would need both to be 'cognizant of the concept of dual use research of concern and aware of the risk that technologies or information produced by life sciences research may be misused' ${ }^{60}$ Indeed, NSABB ${ }^{61}$ places considerable emphasis on improving levels of awareness in that it argues that an 'enhanced culture of awareness is essential to an effective system of oversight and is a critical step in scientists taking responsibility for the dual use potential of their work'.

This chapter argues that ethical discussion and deliberation, alongside consideration of the potential social and legal ramifications of scientific research, ${ }^{62}$ could be usefully embedded in a broader system of scientific oversight such as that envisaged by NSABB, and could have an important deliberative function in assessing experimentation of dual-use concern in the area of plant-science research. Indeed, opportunities for ethical and other types of deliberation could 
be included at each respective step (PIs, institutional and independent review entities, governments, and so on) in the research oversight process as identified by NSABB.

Whilst the publication of the framework proposed by NSABB represented a step-change in thinking about how to address the oversight challenges posed by dual-use research of concern, as argued by NSABB, ${ }^{63}$ deliberative processes will need to be informed by increased levels of awareness and education about dual-use research of concern, including 'all applicable policies as well as the provision of guidance and tools that facilitate compliance with the policies'.

Much work needs to be done by ethicists, however, in respect of how such review processes will be informed by ethical considerations. Indeed, awareness raising, education and training courses will need to be developed that facilitate ethical deliberation around dual-use research of concern but also that facilitate deliberation and assessment of both the legal and the social implications of such research. Such material must also be oriented to provide life scientists with guidance and information that facilitate compliance with relevant guidelines, policies and legislation.

Unfortunately, few accredited university courses or non-accredited short courses currently exist that seek to engage life scientists in deliberation about the ethical, legal and social implications of the scientific research they conduct. One notable exception is a combined hybrid biosafety (bio-risk management) and dual-use biosecurity training course ${ }^{64}$ that is being designed and developed in a collaboration between the University of Bradford, UK, and the Public Health Agency, Canada (PHAC). Following the implementation of Canada's Human Pathogens and Toxins Act, ${ }^{65}$ which sets out a compliance requirement that biosafety officers are trained and have requisite 'qualifications', this initiative seeks to develop training material (with a Canadian focus) that engages life scientists in deliberation about life-science research of potential dual-use concern by addressing a range of dual-use issues of relevance to laboratory biosafety and beyond the laboratory door. It is argued here that this combined biosafety/dual-use biosecurity approach possibly represents a model of best practice for the subsequent development of awareness raising, education and training. The last could be incorporated into the training of plant scientists in order that they are cognisant of dual-use research issues of concern and better able to assess the ethical, legal and social implications of their work.

63 NSABB, op. cit., p. 15

64 The dual-use biosecurity element of this initiative has evolved from an existing online distance-learning course that focuses on applied dual-use biosecurity education that has been running at the University of Bradford since September 2010.

65 Human Pathogens and Toxins Act, 2009, Canada, <http://lois-laws.justice.gc.ca/eng/acts/H-5.67/index.html>. 
Finally, building on research that was previously set out in the influential 2004 Fink Report, ${ }^{66}$ NSABB also set out seven criteria for the identification of 'endeavours' and 'discoveries' that might trigger discussion and review. The following seven classes of experiments might provide a useful framework for considering 'the types of endeavours or discoveries' that, if proposed, might trigger review by PIs including, where appropriate, 'review and discussion by informed members of the scientific and medical community before they are undertaken or, if carried out, before they are published in full detail' ${ }^{67}$

The experiments include those that:

1. Would demonstrate how to render a vaccine ineffective. This would apply to both human and animal vaccines. Creation of a vaccine-resistant smallpox virus would fall into this class of experiments.

2. Would confer resistance to therapeutically useful antibiotics or antiviral agents. This would apply to therapeutic agents that are used to control disease agents in humans, animals, or crops. Introduction of ciprofloxacin resistance in Bacillus anthracis would fall in this class.

3. Would enhance the virulence of a pathogen or render a nonpathogen virulent. This would apply to plant, animal, and human pathogens. Introduction of cereolysin toxin gene into Bacillus anthracis would fall into this class.

4. Would increase transmissibility of a pathogen. This would include enhancing transmission within or between species. Altering vector competence to enhance disease transmission would also fall into this class.

5. Would alter the host range of a pathogen. This would include making nonzoonotics into zoonotics agents. Altering the tropism of viruses would fit into this class.

6. Would enable the evasion of diagnostic/detection modalities. This could include microencapsulation to avoid antibody-based detection and/or the alternation of gene sequences to avoid detection by established molecular methods.

7. Would enable the weaponization of a biological agent or toxin. [Emphasis added]

Whilst a detailed analysis of NSABB's oversight system is beyond the purview of this chapter, the above criteria could be used to trigger interventions

66 Committee on Research Standards and Practices to Prevent the Destructive Application of Biotechnology, Development, Security, and Cooperation, Policy and Global Affairs, op. cit.

67 NSABB, op. cit., p. 18. 
in plant-science research at the level of PI. A multilayered oversight system could include a system of checks and balances so as to ensure that appropriate review is applied, where appropriate to do so, at each stage of the research/ oversight process. Application of the criteria to developments in plant science and technology (as discussed above) would seem to suggest that discussion and review concerning the ethical, legal and social implications of such research would be triggered in no less than five out of seven classes of experiments identified in Fink and by NSABB (see emphases). 